\title{
An Analysis of the First Pillar of the CAP by Evaluating its Selected Indicators and Measuring its Impact on the Performance of Slovenian Agriculture over the Period 2014-2020
}

\author{
Jernej GOLC, Jernej TURK, Jernej PRIŠENK \\ University of Maribor, Faculty of Agriculture and Life Sciences, Pivola 10, 2311 Hoče, Slovenia
}

\begin{abstract}
The Common Agricultural Policy (CAP) has existed at the European Union level since 1962. Over the years, it has undergone various transformations, reforms and adjustments. By measuring the performance of the CAP implementation, the European Union has introduced a model for evaluating individual CAP measures by promoting a system of different indicators which are, through various methods of data and information collection, mostly published annually, while their achieved values are reported to the public. Based on the evaluation of these data, it can be assessed how successfully the CAP influences individual agricultural industries within each country or region. Through its Resolution on the Strategic Guidelines for the Development of Slovenian Agriculture and Food Industry until 2020, Slovenia set its strategic objectives and its own tailored system of indicators for evaluation. Through the analysis of the First Pillar of the CAP, we want to assess the impact of the CAP on Slovenian agriculture in the 2014-2020 period based on the selected indicators, namely organic farming, indicators for the wine sector and two indicators of self-sufficiency assessment for the selected agricultural product - meat. The analysis of the results achieved may be used by decision makers as a basis for assessing the performance CAP measures and input information in the further development of appropriate CAP measures in the future. Obviously, the results are also accessible to the general public, with the possibility to assess the performance of CAP financial assets invested in individual targeted CAP measures and their achievements.
\end{abstract}

Key words: Common Agricultural Policy (CAP), First Pillar, evaluation of indicators, organic farming, wine, self-sufficiency in meat

\section{INTRODUCTION}

Through all periods of its existence, the Common Agricultural Policy (CAP) has been undergoing constant reforms and adjustments according to the situation in agriculture. By adopting the CAP reform in 2013, decision makers set up a system for monitoring and evaluating CAP measures for the 2014-2020 period. Monitoring is established on the basis of a set model of targets accompanied by several types of indicators. The indicator should be quantifiable and provide an option to determine measurable values through a system of measuring and acquiring information and data for the individual value of the indicator.
The respective analysis focused on the impact of the First Pillar of the CAP and graphically presented the structure of the First Pillar of the 2014-2020 CAP. Using publicly available data, we show individual values according to the individual indicator as well as direct payments made and the market measures for Slovenia in the 2014-2018 period.

Slovenia set the objectives of domestic agricultural policy in the Resolution on the Strategic Guidelines for the Development of Slovenian Agriculture and Food Industry until 2020. The Resolution contains 49 operational objectives. In preparing the Evaluation of the Slovenian Agricultural Policy in the 2015-2020 period, Erjavec et al. (2018)

${ }^{*}$ Correspondence to:

E-mail: jernej.prisenk@um.si 
defined the general and derived objectives of the Slovenian agricultural policy and determined the selected indicators.

EU expenditure on direct payments and market measures for Slovenia under the 1st pillar in the 2014-2018 period amounted to $€ 678,014,162$ and $€ 38,962,249$, respectively (European Commission, 2021a). This means that $94.3 \%$ of all funds under the 1st pillar were earmarked for direct payments and $5.7 \%$ for market measures. In our part of the analysis, we have included the results of the indicators for organic farming, indicators for the wine sector, and selected the agricultural product - meat in the indicators of the selfsufficiency level. The obtained results were used to analyse the impact of the CAP on the Slovenian agriculture, while the assessment of the impact on the selected indicators was provided in the conclusion.

\section{Common Agricultural Policy indicators}

The CAP was established at the level of the European Union in 1962 as a partnership between agriculture and human society. Agriculture is facing specific challenges, such as lower income for farmers than in non-agricultural activities, high weather and climate dependency, the occurrence of asynchronicity between consumer demand and the capacity of agricultural production (CRA-INEA, 2015). In order to meet these challenges, CAP was focused on supporting multifunctional role of agriculture by ensuring stable food production, enabling relative sound income levels to farmers and their families, responding to environmental concerns and last but not least retaining the settlement issue as a top agenda in rural areas.

Together with the CAP reform in 2013, a common framework for monitoring and evaluating the performance of CAP implementation in the 2014-2020 period was set up (Table 1). This covered, for the first time, monitoring the First Pillar (direct payments ${ }^{1}$ and market measures ${ }^{2}$ ) and the second pillar (rural development ${ }^{3}$ ) as well as horizontal measures $^{4}$ (e.g. cross-compliance) of the CAP. At the end of 2018, the European Commission prepared a report for the European Parliament and the Council on the implementation of the common monitoring and evaluation framework and the first results on the performance of the CAP (European Commission, 2021c).

Within the legal framework, the Horizontal Regulation ${ }^{5}$ laid down that the performance of CAP is monitored according to three general CAP objectives.

Five types of indicators have been defined to support the assessment of the performance of the CAP. Among them, 16 result indicators ${ }^{6}$ were specified for the First Pillar to measure direct and immediate effects of interventions.

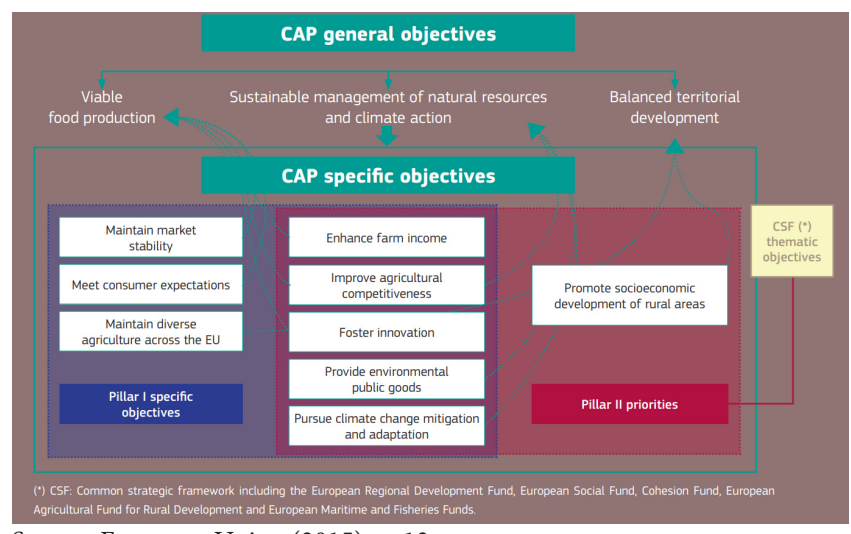

Source: European Union (2015), p. 13

Figure 1: General and specific objectives of the CAP

The European Commission defines indicators as a tool to measure the achievement of the target, while the information based on the indicator is the data used to measure the facts or opinions (European Commission, 2015, p. 13).

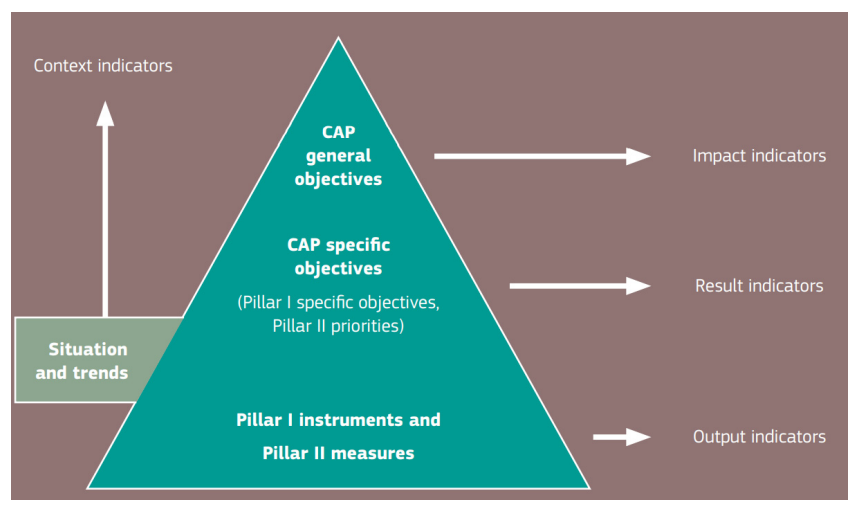

Source: European Union (2015), p. 14

Figure 2: Hierarchy of indicators according to the objectives of the CAP 
Table 1: CAP monitoring and evaluation indicators

\begin{tabular}{|c|c|c|}
\hline \multicolumn{3}{|c|}{ Impact indicators } \\
\hline $\begin{array}{l}\text { 1. Agricultural entrepreneurial income } \\
\text { 2. Agricultural factor income } \\
\text { 3. Total factor productivity in agriculture } \\
\text { 4. EU commodity price variability } \\
\text { 5. Consumer price evolution of food products }\end{array}$ & $\begin{array}{ll}\text { 6. } & \text { Agricultural trade balance } \\
\text { 7. } & \text { Emissions from agriculture } \\
\text { 8. } & \text { Farmland bird index } \\
\text { 9. } & \text { High nature value (HNV) farming } \\
\text { 10. } & \text { Water abstraction in agriculture } \\
\text { 11. } & \text { Water quality }\end{array}$ & $\begin{array}{l}\text { 12. Soil organic matter in arable land } \\
\text { 13. Soil erosion by water } \\
\text { 14. Rural employment rate } \\
\text { 15. Degree of rural poverty } \\
\text { 16. Rural GDP per capita }\end{array}$ \\
\hline \multicolumn{3}{|c|}{ Result indicators } \\
\hline $\begin{array}{l}\text { 1. Share of direct support in agricultural income } \\
\text { 2. Variability of farm income } \\
\text { - by type of farm } \\
\text { - } \quad \text { by economic size } \\
\text { 3. Value added for primary producers in the } \\
\text { food-chain } \\
\text { 4. EU agricultural exports } \\
\text { - share of EU agricultural exports in world } \\
\text { - exports } \\
\text { share of final products in EU agricultural } \\
\text { exports } \\
\text { 5. Public intervention: \% volume of products } \\
\text { bought in intervention storage out of total } \\
\text { EU production } \\
\text { 6. Private storage: \% volume of products in } \\
\text { private storage out of total EU production }\end{array}$ & $\begin{array}{l}\text { 7. } \begin{array}{l}\text { Export refunds: \% volume } \\
\text { of products exported with } \\
\text { export refunds out of total EU } \\
\text { production }\end{array} \\
\text { 8. } \begin{array}{l}\text { EU commodity prices compared } \\
\text { to world prices (broken down by } \\
\text { product) }\end{array} \\
\text { 9. } \quad \begin{array}{l}\text { Value of production under EU } \\
\text { quality schemes compared to }\end{array} \\
\text { total value of agricultural and } \\
\text { food production } \\
\text { 10. Importance of organic farming } \\
\text { share of organic area in total } \\
\text { utilised agricultural area (UAA) } \\
\text { share of organic livestock in total } \\
\text { livestock }\end{array}$ & 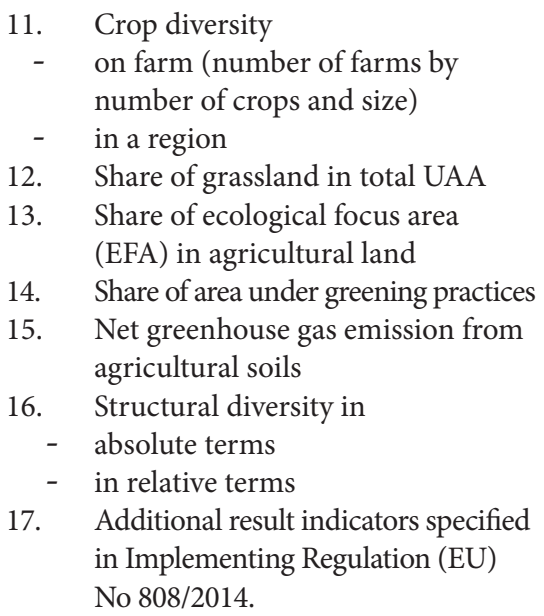 \\
\hline
\end{tabular}

Basic payment scheme

- Number of farmers

- Number of hectares

Single area payment scheme

- Number of farmers

- Number of hectares

Transitional national aid (TNA)

- $\quad$ Number of farmers

- Number of units for which TNA is granted (hectares/animals/ other)

Redistributive payment

- Number of farmers

- Number of hectares

Greening

- Total number of farmers who have to apply at least one greening obligation

- Total number of hectares declared by those farmers

Greening exemptions

- Number of farmers exempted by: organic farmers/exempted from crop diversification/exempted from EFA obligation

- Number of hectares declared by these farmers (organic farmers/ exempted from crop diversification/exempted from EFA obligation)

Crop diversification

- $\quad$ Number of farmers subject to crop diversification (with 2 crops; with 3 crops)

- Number of hectares of arable land declared by farmers subject to crop diversification (with 2 crops; with 3 crops)

Permanent grassland

- $\quad$ Number of farmers with permanent grassland counting for the ratio

- Number of hectares covered by permanent grassland declared by the farmers counting for the ratio

- $\quad$ Number of farmers with permanent grassland in designated environmentally sensitive areas

- Number of hectares covered by environmentally sensitive permanent grassland declared by these farmers

- Number of hectares of designated environmentally sensitive permanent grassland (total)
Ecological Focus Areas (EFA)

- Number of farmers subject to EFA requirements

- Number of hectares of arable land declared by farmers subject to EFA

- Number of hectares declared by farmers as EFA, broken down by EFA type

Equivalence

- Number of farmers applying equivalent measures (certification schemes or agrienvironment-climate measures)

- Number of hectares declared by farmers implementing equivalent measures (certification schemes or agri-environment-climate measures)

Payment for young farmers

- Number of farmers

- $\quad$ Number of hectares

Small farmers' scheme

- Number of farmers

- Number of hectares

Voluntary coupled support

- Number of beneficiaries of voluntary coupled support (broken down by sector)

- Quantities eligible (number of hectares/number of animals broken down by sector)

- $\quad$ Number of hectares

- Number of animals

Payment for areas with natural constraints

- Number of farmers

- Number of hectares

National programmes for the cotton sector

- Number of farmers

- Number of hectares 


\begin{tabular}{|c|c|}
\hline \multicolumn{2}{|c|}{ Market measures } \\
\hline $\begin{array}{l}\text { Public intervention } \\
-\quad \text { Volume } \\
-\quad \text { Duration } \\
\text { Private storage } \\
-\quad \text { Volume } \\
-\quad \text { Duration } \\
\text { Export refunds } \\
-\quad \text { Volume of products exported with export refunds } \\
\text { Exceptional measure } \\
-\quad \text { [as appropriate] } \\
\text { Producer organisations } \\
-\quad \text { \% of production marketed by producer organisations } \\
\quad \text { and associations of producer organisations }\end{array}$ & 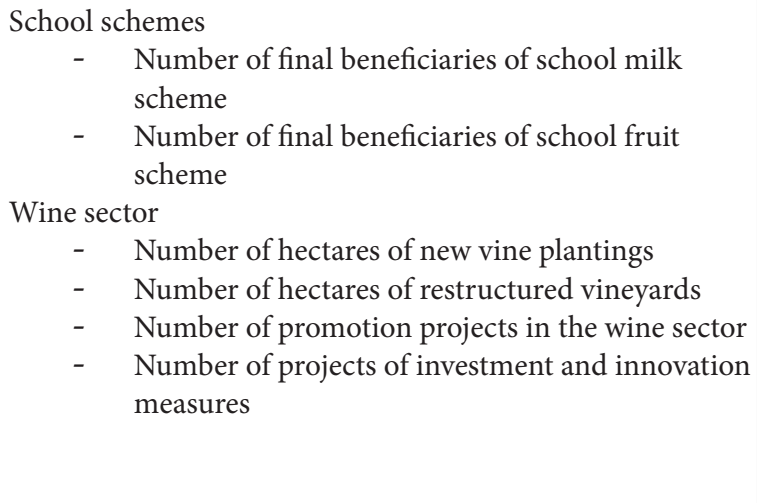 \\
\hline \multicolumn{2}{|c|}{ Horizontal aspects } \\
\hline $\begin{array}{l}\text { Cross compliance } \\
\text { - Number of hectares subject to cross-compliance } \\
\text { - } \quad \text { Share of CAP payments subject to cross-compliance } \\
\text { Quality policy } \\
\text { - } \quad \text { Geographical indications in the wine sector } \\
\text { - Number of new protected designations of origin, protected } \\
\quad \text { geographical indication and traditional speciality guaranteed by } \\
\text { sector }\end{array}$ & $\begin{array}{l}\text { Organic farming } \\
-\quad \text { Number of hectares (total and under } \\
\text { - } \quad \text { Numbersion) } \\
\text { Promotion policy } \\
\text { - Number of programmes (in and outside the EU) } \\
\text { - } \quad \text { Number of new proposing organisations } \\
\text { Farm advisory system } \\
\text { - Number of farmers advised }\end{array}$ \\
\hline \multicolumn{2}{|c|}{ Rural Development } \\
\hline $\begin{array}{l}\text { The output indicators specified in Implementing Regulation (EU) No } \\
808 / 2014 \text {. }\end{array}$ & \\
\hline Context indica & \\
\hline
\end{tabular}

Source: Adapted from Commission Implementing Regulation (EU) No 834/2014 of 22 July 2014 (European Union, 2014)

\section{Structure of the $1^{\text {st }}$ pillar of the CAP}

Instruments of the First Pillar contribute to achieving the specific objectives and, in fact, the general objectives of the CAP as well. Direct payments support (Table 2) and facilitate stable income for farmers, improve competitiveness and contribute to the provision of environmental public goods, climate change mitigation and adaptation. Market measures (Table 3) provide for safeguard mechanisms in times of market disturbance or crisis, thereby preserving market stability and helping to meet consumer expectations (European Commission, 2015, p. 12; MAFF, 2019).

\section{Objectives of Slovenian agricultural policy for 2014-2020}

The first objectives of the Slovenian agricultural policy after accession to the EU can be found in the Agriculture Act, which was adopted in 2008. An important document outlining the objectives of the Slovenian agricultural policy is the Resolution on the Strategic Guidelines for the Development of Slovenian Agriculture and Food Industry until 2020 - "Ensuring Food for Tomorrow" (Official Gazette of the Republic of Slovenia, 2011). Chapter 4.2 of the respective document states the Strategic Objectives of the Development of the Slovenian

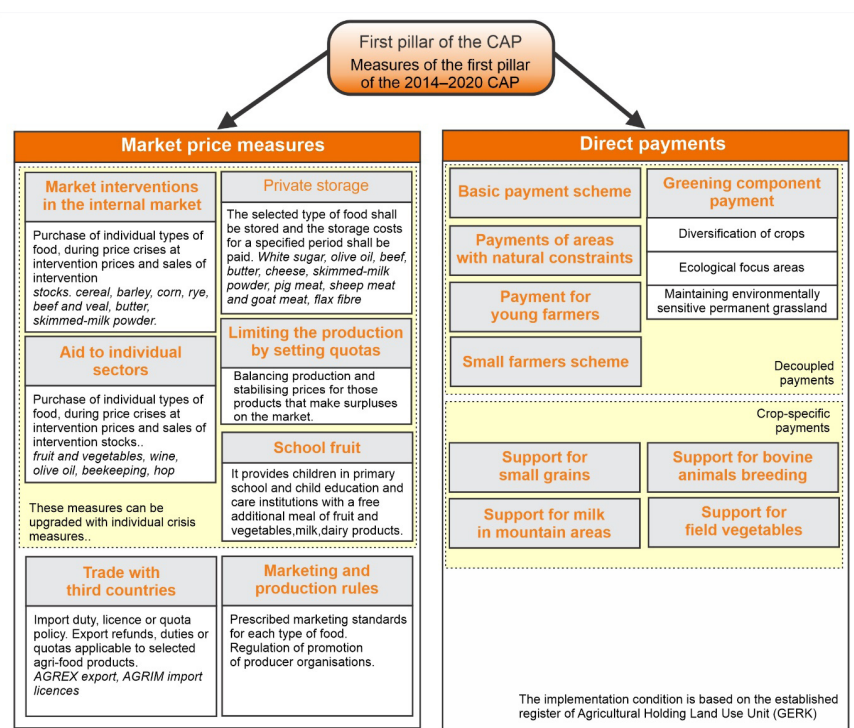

Source: Adapted from Turk (2021), p. 79.

Figure 3: Graphic diagram of the First Pillar of the 20142020 CAP

Agriculture and Food Industry:

- Ensuring food security through stable production of safe, quality food accessible to consumers.

- Increasing the competitive capacity of agriculture and agrifood sector. 
Table 2: Pillar I EU expenditure in $€$ on direct payments for Slovenia in the 2014-2018 period

\begin{tabular}{|l|c|c|c|c|c|}
\hline \multicolumn{1}{|c|}{ Indicator name } & $\mathbf{2 0 1 4}$ & $\mathbf{2 0 1 5}$ & $\mathbf{2 0 1 6}$ & $\mathbf{2 0 1 7}$ & $\mathbf{2 0 1 8}$ \\
\hline $\begin{array}{l}\text { Expenditure direct } \\
\text { payments }\end{array}$ & $135,982,928.00$ & $137,618,722.00$ & $135,770,967.00$ & $134,875,841.00$ & $134,688,867.00$ \\
\hline $\begin{array}{l}\text { Expenditure basic payment } \\
\text { scheme }\end{array}$ & & $72,116,427.75$ & $70,940,455.40$ & $71,128,359.07$ & $71,601,428.70$ \\
\hline Expenditure greening & & $40,795,315.66$ & $40,260,646.11$ & $40,330,807.69$ & $39,816,552.30$ \\
\hline Expenditure young farmers & & $2,711,788.98$ & $2,709,022.78$ & $2,619,953.05$ & $2,654,148.85$ \\
\hline Expenditure small farmers & & $860,991.84$ & $785,982.71$ & $487,877.02$ & $363,895.01$ \\
\hline $\begin{array}{l}\text { Expenditure voluntary } \\
\text { coupled support }\end{array}$ & & $20,239,250.05$ & $20,072,187.58$ & $17,284,129.99$ & $17,231,210.86$ \\
\hline $\begin{array}{l}\text { Expenditure areas with } \\
\text { natural constraints }\end{array}$ & 0 & 894,948 & $1,002,672$ & 904,656 & $2,098,468.98$ \\
\hline SPS reimbursement & & & & $2,120,057.81$ & 2 \\
\hline
\end{tabular}

Source: processed and adapted from agridata.ec.europa.eu (April 2021)

Table 3: Pillar I EU expenditure in $€$ on market measures for Slovenia in the 2014-2018 period

\begin{tabular}{|l|c|c|c|c|c|}
\hline Indicator name & $\mathbf{2 0 1 4}$ & $\mathbf{2 0 1 5}$ & $\mathbf{2 0 1 6}$ & $\mathbf{2 0 1 7}$ & $\mathbf{2 0 1 8}$ \\
\hline Total market measures & $7,020,933.00$ & $8,655,918.00$ & $8,581,199.00$ & $7,341,839.00$ & $7,362,360.00$ \\
\hline Market measures for wine & $5,040,265.00$ & $5,038,879.00$ & $5,045,000.00$ & $5,044,945.00$ & $5,045,000.00$ \\
\hline Milk and milk products & 0 & $1,094,746.00$ & $1,253,164.00$ & 0 & 0 \\
\hline Promotion activities & $507,505.00$ & $306,645.00$ & $596,176.00$ & $1,002,902.00$ & $1,017,140.00$ \\
\hline Fruit and vegetables & $474,678.00$ & $860,479.00$ & $610,190.00$ & 0 & 0 \\
\hline $\begin{array}{l}\text { School schemes (fruit and } \\
\text { milk) }\end{array}$ & $723,679.00$ & $799,436.00$ & $794,310.00$ & $950,113.00$ & $953,937.00$ \\
\hline Bee-keeping & $274,805.00$ & $282,046.00$ & $282,360.00$ & $343,879.00$ & $346,283.00$ \\
\hline Other markets & 1.00 & $273,687.00$ & 1.00 & 0 & 0 \\
\hline
\end{tabular}

Source: processed and adapted from agridata.ec.europa.eu (April 2021)

- Sustainable use of production potential and providing agriculture-related public goods.

- Ensuring coherent and socially sustainable rural development (in cooperation with other policies). In order to implement the respective resolution, in 2014, the Ministry of Agriculture and the Environment approached the drawing up of the Resolution on the Strategic Guidelines for the Development of Slovenian Agriculture and Food Industry until 2020, which would be crucial for achieving the adopted objectives and priority programme policies. Its introductory part indicates that the primary purpose of the strategy is to define key measures and activities that would enable the objectives set out in the resolution to be achieved (MAFF, 2014). The eDemokracija portal, which operates as part of electronic administration of the Republic of Slovenia eUprava, shows that the Implementing Strategy of the Resolution on the Strategic Guidelines for the Development of Slovenian Agriculture and Food Industry until 2020 was included in the meeting of working parties in the National

7 SPS=single payment scheme. Reimbursement of direct payments to farmers from appropriations carried over in relation to financial discipline and some residual payments for the former single payment scheme (SPS).
Assembly in June 2014, but also indicates that the strategy status is still in process - March 2021 (E-democracy, 2014).

The resolution sets out the priority programme guidelines which refer to the implementation level. These guidelines combine the specific and programme objectives of the CAP and the specific needs of Slovenian agriculture and rural areas. The problem that is being detected is the linking of programme policies to CAP measures. Links established between priority guidelines and measures are rather general and vague. In particular, this is evident in the First Pillar, where most of the funds through direct payments are allocated to solving income problems in agriculture (Erjavec et al., 2018, p. 30). Erjavec et al. (2018) find that the resolution contains 49 operational objectives that are partially appropriate for evaluation (Table 4). The authors highlight the problem of an excessive number of operational objectives where they are duplicated or there are several objectives in one. For that reason, four general objectives of the Slovenian agricultural policy and 18 derived objectives were defined in drawing up the Evaluation of the Slovenian Agricultural Policy in the 2015-2020 period. Thus, the defined objectives stem from both the resolution and the CAP, specified by the European Commission. 
Table 4: Indicators according to the general and derived objectives of the Slovenian agricultural policy

\begin{tabular}{|c|c|c|}
\hline General objective & $\begin{array}{l}\text { Derived } \\
\text { objective }\end{array}$ & Selected indicators \\
\hline \multirow{7}{*}{$\begin{array}{l}\text { RESILIENT AND } \\
\text { COMPETITIVE } \\
\text { PRODUCTION }\end{array}$} & Food security & $\begin{array}{l}\text { - Self-sufficiency rate for selected agricultural products } \\
\text { - Trade balance in the agri-food industry }\end{array}$ \\
\hline & $\begin{array}{l}\text { Income } \\
\text { situation }\end{array}$ & $\begin{array}{l}\text { - Agricultural factor income } \\
\text { - } \text { Standard income per agricultural holding by types of farming } \\
\end{array}$ \\
\hline & $\begin{array}{l}\text { Income } \\
\text { stability }\end{array}$ & $\begin{array}{l}\text { - Value of agricultural production } \\
\text { - Price indices of agricultural crops in producers } \\
\text { - Proportion of subsidies in factor income } \\
\text { - Agricultural production insurance }\end{array}$ \\
\hline & $\begin{array}{l}\text { Efficient use } \\
\text { of resources }\end{array}$ & $\begin{array}{l}\text { - Proportion of gross added value of agriculture } \\
\text { - Labour productivity in agriculture } \\
\text { - Intensity of cultivation for important agricultural crops } \\
\text { - } \quad \text { Average size of agricultural holdings } \\
\text { - } \quad \text { Size structure of agricultural holdings } \\
\text { - Logging in Slovenian forests }\end{array}$ \\
\hline & $\begin{array}{l}\text { Accessibility } \\
\text { of resources }\end{array}$ & $\begin{array}{l}\text { - Basic production factors in managing agricultural holdings } \\
\text { - } \text { Proportion of agricultural land used in respect of all agricultural land }\end{array}$ \\
\hline & Value chains & $\begin{array}{l}\text { - Proportion of gross added value of food industry } \\
\text { - Labour productivity in the food-processing industry } \\
\text { - } \text { Proceeds from the sale of food products and share of export }\end{array}$ \\
\hline & Food safety & $\begin{array}{l}\text { - } \quad \text { Level of pesticide residues in food } \\
\text { - } \quad \text { Residues of medicines used in veterinary medicinal products } \\
\text { - } \quad \text { Budgetary resources for measures related to food safety and quality }\end{array}$ \\
\hline $\begin{array}{l}\text { SUSTAINABLE } \\
\text { MANAGEMENT } \\
\text { OF NATURAL } \\
\text { RESOURCES AND } \\
\text { THE PROVISION } \\
\text { OF PUBLIC } \\
\text { GOODS }\end{array}$ & $\begin{array}{l}\text { Climate } \\
\text { change }\end{array}$ & $\begin{array}{l}\text { - Greenhouse gas emissions from agriculture } \\
\text { - Energy use in agriculture, forestry and food industry } \\
\text { - Renewables from agriculture and forestry } \\
\text { - Irrigation of agricultural land }\end{array}$ \\
\hline
\end{tabular}

Source: Erjavec et al. (2018), p. 59

\section{Selected effects of the $1^{\text {st }}$ Pillar of the CAP on Slovenian agriculture}

Out of CAP monitoring and evaluating indicators and indicators based on the general and derived objectives of the Slovenian agricultural policy, only a few have been selected that can be linked with the measures of the First Pillar of the $\mathrm{CAP}$ and detected in evaluating the CAP as well as in general and derived objectives of the Slovenian agricultural policy.

The analysis took into account the EU expenditure referred to in tables 5 and 6, which was allocated to Slovenia and the link of the earmarked values by individual measures that would have the most impact on the selected indicator. There are difficulties because each individual measure has a large number of sub-measures that are intertwined, and each indicator is not influenced by just one measure. For example, the indicator Number of organic farms can be influenced by various measures under the First Pillar (for example: direct payments in the context of the payment of greening component for ecological focus areas) as well as market measures (for example, school fruit where fruit is provided in schools to children, such as organic apples or other fruit). Such an analysis would require significantly more precise basic data on the volume consumption of fruit in the school fruit scheme and fruit prices. The same applies to direct payments. It would be necessary to obtain more precise information on the involved farms with ecological focus areas, as farms with no organic certificate also receive the aid.

\section{Results of the indicator on organic farming}

In terms of general objectives, the selected indicator on Agricultural land with organic production in the Slovenian agricultural policy belongs to Sustainable management of natural resources and provision of public goods, while according to the derived objectives to Soil protection. Under the CAP, however, the indicator under the field of Organic farming falls within the indicator of Realisation according to horizontal aspects.

The data obtained show there were 2,232 agricultural holdings with organic production in Slovenia in 2013, 
Table 5: Agricultural land with organic production

\begin{tabular}{|l|c|c|c|c|c|c|c|}
\hline & $\mathbf{2 0 1 3}$ & $\mathbf{2 0 1 4}$ & $\mathbf{2 0 1 5}$ & $\mathbf{2 0 1 6}$ & $\mathbf{2 0 1 7}$ & $\mathbf{2 0 1 8}$ & $\mathbf{2 0 1 9}$ \\
\hline Number of organic farms & 2,232 & 2,537 & 2,699 & 2,933 & 3,190 & 3,320 & 3,494 \\
\hline $\begin{array}{l}\text { Surface of organic agricultural land } \\
\text { in use (ha) }\end{array}$ & 30,041 & 33,536 & 32,488 & 36,353 & 40,349 & 41,669 & 44,455 \\
\hline $\begin{array}{l}\text { Average size of organic farms in } \\
\text { Slovenia (ha) }\end{array}$ & 13 & 13 & 12 & 12 & 13 & 13 & 13 \\
\hline Farms in conversion & 817 & 761 & 718 & 585 & 445 & 421 & 334 \\
\hline
\end{tabular}

Source: processed and adapted from MKGP and SURS (2021)

while in 2019 this number was 56\% higher, namely 3,494 agricultural holdings. The area of organic agricultural land increased from 30,041 ha in 2013 to 44,455 ha in 2019. The average size of a farm pursuing organic farming in Slovenia is $13 \mathrm{ha}$ and is almost twice the average size of an agricultural holding in Slovenia, which was 7 ha in $2020 .{ }^{1}$ It is also positive that the share of agricultural holdings and size of land used to pursue organic farming increased from $5.2 \%$ in 2010 to $9.2 \%$ in 2020. The percentage of farms producing organic crops also increased in comparison to all agricultural holdings, i.e. from $2.5 \%$ to $5.1 \%$ of farms (Table 5 ).

The impact of the CAP under the First Pillar on agricultural holdings and land with organic production in Slovenia can be associated with the amounts of direct payments, where organic farms have slightly lower entry conditions to direct payments in terms of minimum land size or livestock unit per ha and other possible lower entry conditions for accessing direct payments.

In analysing the effects of the CAP under the First Pillar on the indicator on organic farms, it is also necessary to take into account that entry of a farm into organic farming takes place through a conversion rate of a minimum of 2 years. That is why we have decided to upgrade this indicator and, in the analysis, also take into account the data on agricultural holdings that are already in the conversion phase. The data indicate that, from 2013, when 817 farms were in the conversion phase, up to 2019, the number of farms in conversion is in decline; namely only 334 farms in 2019. It is also a fact that, in 2020, there were 139 organic farms fewer than in 2019. According to the Slovenian Organic Farmers' Association (S.O.F.A.), 266 farms with 2,220 ha of agricultural land withdrew from the organic control in 2020.

It can be estimated from the above that the impact of the increase in organic farms in the 2014-2020 period is associated with the measures of the previous financial perspective of the CAP.

However, the impact on the indicator on ecological farms under the 2014-2020 CAP may even be expected to be negative in view of the trend of the number of farms in the conversion phase towards organic farming in recent years.

\footnotetext{
1 In 2020, there were 67,927 agricultural holdings and 482,359ha of agricultural land in Slovenia (SORS, 2021)
}

\section{Results of indicators for the wine sector}

Within the scope of the First Pillar for market price measures as an aid to each sector in the case of wine, the EU allocated a total of $€ 25,214,089$ to Slovenia in the 2014-2018 period. This measure includes support for restructuring vineyards and support for the promotion of wine. The aid for restructuring vineyards may be claimed by beneficiaries planting vines under a permit for replanting vines (Table 6). The aid for the promotion of wine includes promotional activities, such as publication of advertisements in the media, preparation of advertising material, participation in trade fairs and other events, preparation of market research and organisation of seminars for journalists, importers, professional public and third-country consumers. The aid may also be granted for providing information in the Member States and for fair and promotional activities in target markets (European Commission, 2021b).

About 15,500 ha of vineyards (MAFF, 2018) are entered in the Register of Grape and Wine Growers (RPGV). Table 6 shows that, through EU market measures, a total of 1,564 ha of vineyards were restructured and replanted from 2014 to 2018 , which is $10 \%$ of all vineyard areas in Slovenia.

\section{Results of the indicator on self-sufficiency rate for selected agricultural product - Meat}

In the indicators according to general and derived objectives of the Slovenian agricultural policy, the indicator "Self-sufficiency rate for selected agricultural products" which fall under the derived objectives "Food security" and the general objective "Resilient and competitive production" were selected. In order to carry out the impact analysis of the First Pillar of the CAP, the agricultural product selected is meat which, according to the available data, is classified with seven attributes (meat of bovine animals, pig meat, sheep and goat meat, horse meat, offal and other meat) (Table 7).

The link between the CAP measures from the First Pillar and the self-sufficiency rate for the selected agricultural product may be found in different measures in direct payments; support to rearing of bovine animals, payments for areas with natural constraints and other measures under the First Pillar.

Table 7 shows domestic meat production, which indicates that just over 153,540 tonnes of meat was produced in 2019 in Slovenia, i.e. 9.8\% more than in 2014 with 139,810 tonnes. In 2019, Slovenia produced more meat in all the 
Table 6: Values of indicators for the market price measure to aid the wine sector

\begin{tabular}{|l|c|c|c|c|c|c|c|}
\hline & unit & $\mathbf{2 0 1 4}$ & $\mathbf{2 0 1 5}$ & $\mathbf{2 0 1 6}$ & $\mathbf{2 0 1 7}$ & $\mathbf{2 0 1 8}$ & Total 2014-2018 \\
\hline $\begin{array}{l}\text { Number of hectares of new vine } \\
\text { plantings granted }\end{array}$ & (ha) & - & - & 33.90 & 93.00 & 90.58 & 217.48 \\
\hline $\begin{array}{l}\text { Number of hectares of } \\
\text { restructured vineyards }\end{array}$ & (ha) & 270 & 235 & 352 & 262 & 228 & 1,347 \\
\hline $\begin{array}{l}\text { Number of promotion projects } \\
\text { in the wine sector }\end{array}$ & (number) & 144 & 219 & 336 & 18 & 269 & 986 \\
\hline
\end{tabular}

Source: processed and adapted from agridata.ec.europa.eu (April 2021)

categories considered, except for horse meat, which recorded a $10 \%$ decrease. The largest surge was achieved by poultry production by $+14 \%$ and meat of bovine animals by $+8.8 \%$. Total meat consumption in Slovenia was $8.2 \%$ higher, i.e. 189,650 tonnes in 2019 compared to 175,220 tonnes in 2014 . The consumption of horse meat by $23 \%$ and the meat of small cattle fell by $1.2 \%$, i.e. 1,830 tonnes in 2019 (Table 8 and 9).
In the analysis, the data for meat production in Slovenia, consumption of meat in Slovenia and the data with regard to the consumption of individual type of meat per capita at annual level in $\mathrm{kg}$ were used. In the 2014-2019 period, the meat consumption per capita per year in Slovenia increased by more than $5 \mathrm{~kg}$ and amounted to $90.9 \mathrm{~kg}$ in 2019 . Poultry meat consumption per capita increased by $13.4 \%(30.63 \mathrm{~kg}$

Table 7: Domestic meat production in 1,000 t in the 2013-2019 period

\begin{tabular}{|l|c|c|c|c|c|c|c|}
\hline & $\mathbf{2 0 1 3}$ & $\mathbf{2 0 1 4}$ & $\mathbf{2 0 1 5}$ & $\mathbf{2 0 1 6}$ & $\mathbf{2 0 1 7}$ & $\mathbf{2 0 1 8}$ & $\mathbf{2 0 1 9}$ \\
\hline Meat of bovine animals & 41.09 & 39.59 & 38.64 & 44.36 & 47.42 & 44.96 & 43.08 \\
\hline Pig meat & 29.00 & 29.57 & 26.39 & 29.00 & 29.54 & 29.47 & 30.54 \\
\hline Sheep meat and goat meat & 1.61 & 1.62 & 1.67 & 1.64 & 1.72 & 1.81 & 1.70 \\
\hline Horse meat & 0.70 & 0.74 & 0.58 & 0.63 & 0.64 & 0.60 & 0.67 \\
\hline Poultry meat & 59.83 & 61.96 & 61.41 & 66.06 & 70.23 & 70.77 & 70.74 \\
\hline Other meat & 0.48 & 0.48 & 0.48 & 0.57 & 0.56 & 0.57 & 0.56 \\
\hline Offal & 5.96 & 5.84 & 5.55 & 6.28 & 6.63 & 6.38 & 6.25 \\
\hline Meat - total & 138.66 & 139.81 & 134.73 & 148.55 & 156.72 & 154.57 & 153.54 \\
\hline
\end{tabular}

Source: processed and adapted from SURS (2021)

Table 8: Domestic meat consumption in 1,000t in the 2013-2019 period

\begin{tabular}{|l|c|c|c|c|c|c|c|}
\hline & $\mathbf{2 0 1 3}$ & $\mathbf{2 0 1 4}$ & $\mathbf{2 0 1 5}$ & $\mathbf{2 0 1 6}$ & $\mathbf{2 0 1 7}$ & $\mathbf{2 0 1 8}$ & $\mathbf{2 0 1 9}$ \\
\hline Meat of bovine animals & 38.24 & 37.23 & 39.18 & 41.19 & 42.92 & 41.07 & 42.01 \\
\hline Pig meat & 73.18 & 75.90 & 76.37 & 84.11 & 77.73 & 78.36 & 76.34 \\
\hline Sheep meat and goat meat & 1.69 & 1.86 & 1.95 & 2.01 & 1.90 & 1.96 & 1.83 \\
\hline Horse meat & 0.32 & 0.35 & 0.32 & 0.30 & 0.30 & 0.25 & 0.27 \\
\hline Poultry meat & 50.99 & 55.64 & 59.58 & 61.90 & 64.22 & 64.64 & 64.00 \\
\hline Other meat & 0.53 & 0.63 & 0.79 & 0.87 & 1.00 & 0.99 & 1.19 \\
\hline Offal & 4.39 & 3.60 & 4.03 & 4.12 & 4.26 & 4.42 & 4.02 \\
\hline Meat - total & 169.34 & 175.22 & 182.21 & 194.50 & 192.33 & 191.68 & 189.65 \\
\hline
\end{tabular}

Source: processed and adapted from SURS (2021) 
Table 9: Meat consumption in kg per capita in Slovenia in the 2013-2019 period

\begin{tabular}{|l|c|c|c|c|c|c|c|}
\hline & $\mathbf{2 0 1 3}$ & $\mathbf{2 0 1 4}$ & $\mathbf{2 0 1 5}$ & $\mathbf{2 0 1 6}$ & $\mathbf{2 0 1 7}$ & $\mathbf{2 0 1 8}$ & $\mathbf{2 0 1 9}$ \\
\hline Meat of bovine animals & 18.57 & 18.06 & 18.99 & 19.96 & 20.77 & 19.84 & 20.11 \\
\hline Pig meat & 35.54 & 36.82 & 37.02 & 40.75 & 37.62 & 37.85 & 36.54 \\
\hline Sheep meat and goat meat & 0.82 & 0.90 & 0.95 & 0.97 & 0.92 & 0.95 & 0.88 \\
\hline Horse meat & 0.15 & 0.17 & 0.16 & 0.15 & 0.15 & 0.12 & 0.13 \\
\hline Poultry meat & 24.76 & 26.99 & 28.88 & 29.99 & 31.08 & 31.23 & 30.63 \\
\hline Other meat & 0.26 & 0.31 & 0.38 & 0.42 & 0.48 & 0.48 & 0.57 \\
\hline Offal & 2.13 & 1.75 & 1.95 & 1.99 & 2.06 & 2.14 & 1.92 \\
\hline Meat - total & 82.24 & 84.99 & 88.32 & 94.22 & 93.08 & 92.60 & 90.77 \\
\hline
\end{tabular}

Source: processed and adapted from SURS (2021)

in 2019). Consumption of meat of bovine animals per capita increased by $11.3 \%(20.11 \mathrm{~kg}$ in 2019$)$. Pig meat consumption remained almost at the same level, namely $36.54 \mathrm{~kg}$, which was the largest share of individual meat type in $\mathrm{kg}$ per capita. The consumption of small cattle meat decreased by $3 \%$ to $0.88 \mathrm{~kg}$ per capita in 2019 , while horse meat consumption decreased by $24 \%$ per capita and amounted to only $0.13 \mathrm{~kg}$ per capita in 2019.
In the indicator on the self-sufficiency rate, the analysis was conducted for the selected agricultural product - meat, which is structured according to the different types of meat on the basis of the availability of the data. Data show that while the self-sufficiency in meat in 2019 is $1 \%$ higher (81\%) than in 2014 , it is still $1 \%$ lower compared to $2013 \%$. The figure 4 above shows that self-sufficiency was the lowest in

Table 10: Self-sufficiency rate in meat in \% for Slovenia in the 2013-2019 period

\begin{tabular}{|l|c|c|c|c|c|c|c|}
\hline & $\mathbf{2 0 1 3}$ & $\mathbf{2 0 1 4}$ & $\mathbf{2 0 1 5}$ & $\mathbf{2 0 1 6}$ & $\mathbf{2 0 1 7}$ & $\mathbf{2 0 1 8}$ & $\mathbf{2 0 1 9}$ \\
\hline Meat of bovine animals & 107.44 & 106.33 & 98.62 & 107.69 & 110.48 & 109.47 & 102.54 \\
\hline Pig meat & 39.63 & 38.95 & 34.56 & 34.48 & 38.00 & 37.62 & 40.01 \\
\hline Sheep meat and goat meat & 95.37 & 87.39 & 85.39 & 81.71 & 90.43 & 92.40 & 93.01 \\
\hline Horse meat & 218.87 & 212.57 & 181.37 & 210.30 & 209.21 & 238.74 & 247.96 \\
\hline Poultry meat & 117.35 & 111.36 & 103.08 & 106.71 & 109.36 & 109.49 & 110.54 \\
\hline Other meat & 90.07 & 76.23 & 61.17 & 65.37 & 56.06 & 58.05 & 47.22 \\
\hline Offal & 135.57 & 162.20 & 137.82 & 152.69 & 155.63 & 144.32 & 155.48 \\
\hline Meat - total & 81.88 & 79.79 & 73.94 & 76.37 & 81.49 & 80.64 & 80.96 \\
\hline
\end{tabular}

Source: processed and adapted from SURS (2021)

2015 , namely $73.9 \%$. This is due to lower production of pig meat and meat of bovine animals, while the consumption of meat of bovine animals and pig meat increased in 2015. In 2016, however, the production of pig meat and meat of bovine animals started to increase and thus the self-supply in meat started to gradually reach $80 \%$.

The increase in meat production in Slovenia in the 20142020 period is $9.8 \%$, which is more than the increase in meat consumption per capita, i.e. $6.8 \%$. It can be assumed that the increase in domestic meat consumption is due to the increased number of residents in Slovenia as well as the increased number of foreign tourists in Slovenia and their consumption in gastronomy.

Slovenia has the lowest self-sufficiency rate in pig meat; namely $40 \%$ in 2019; however, it is consumed the most in $\mathrm{kg}$ per capita, i.e. $36.5 \mathrm{~kg}$ per year. The self-sufficiency rate in sheep meat and goat meat production is $93 \%$ in 2019 . Slovenia has the highest self-sufficiency rate in horse meat production; namely $247 \%$, but the consumption per capita is only $0.13 \mathrm{~kg}$ annually. This is followed by poultry meat with $110 \%$ and meat of bovine animals with $102 \%$; both data are subject to the self-sufficiency rate for 2019.

\section{DISCUSSION}

The introductory chapters present the First Pillar of the EU's CAP, for which expenditure for Slovenia in the context of direct payments and market price measures is shown. To carry out the analysis of the first pillar of the CAP and 


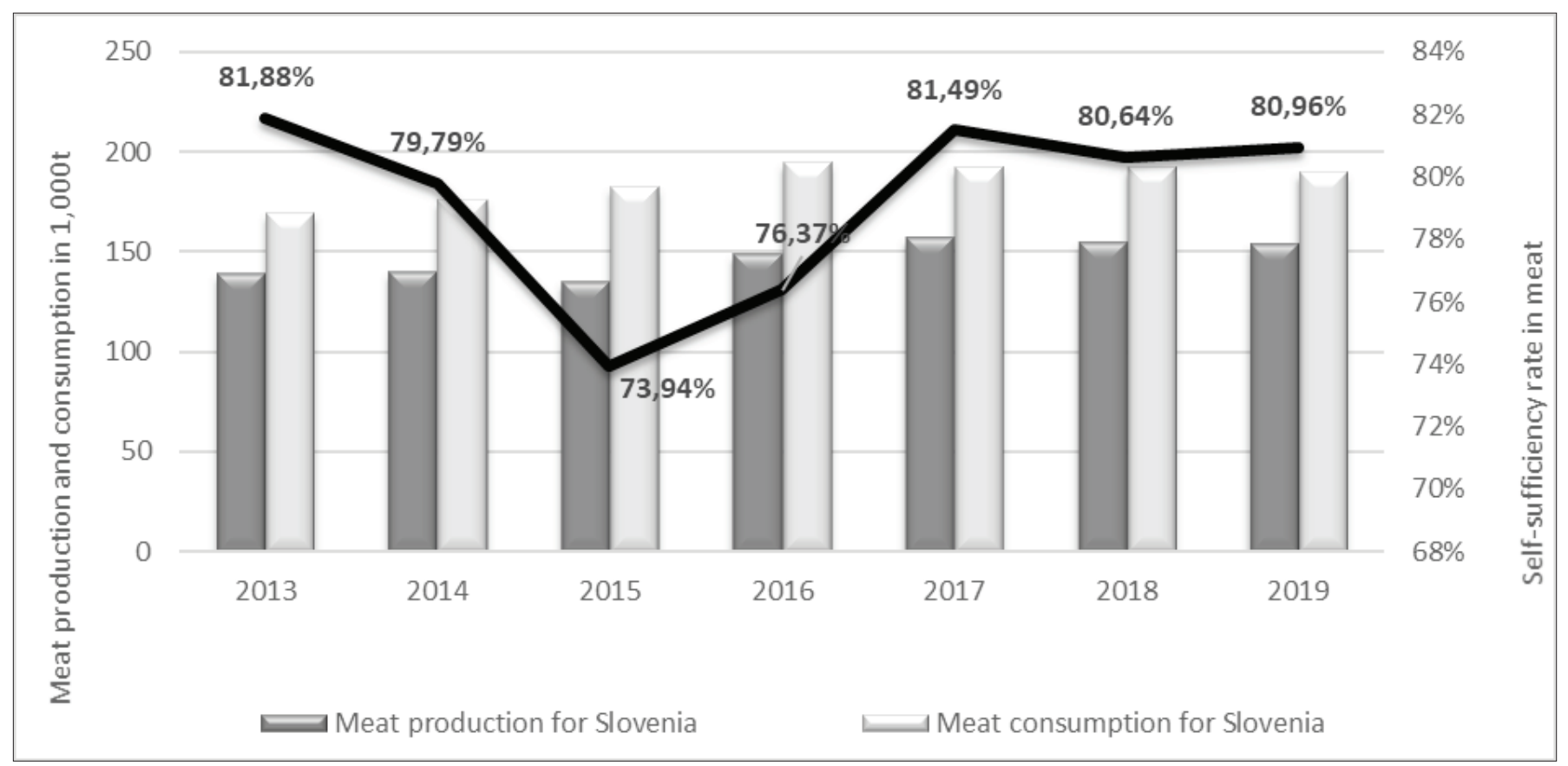

Source: processed and adapted from SURS (2021)

Figure 4: The analysis of the level of self-sufficiency in meat in Slovenia (2013-2019)

its impact on Slovenian Agricultural Policy, three different indicators, were selected. The first indicator "Organic farming" lies both in the CAP and in the evaluation of the Slovenian agricultural policy. The second indicator for the wine sector is in the CAP. The third indicator concerning the self-sufficiency rate for selected agricultural products is in the evaluation of the Slovenian agricultural policy, whereby only one selected agricultural product, i.e. meat, is addressed. The latest data available and used are for 2019.

In the 2014-2019 period, the EU allocated $€ 678,014,163$ to Slovenia under the first pillar for direct payments and market price measures. Certainly, this financial amount has an impact on Slovenian agriculture, as evident in the case of selected indicators considered. Organic farms are facing different problems, as can be seen in the number of farms entering the conversion phase to pursue organic farming; without financial aid of the CAP, the number of these farms would be even lower. Probably, further action will be needed in this field if a $25 \%$ share of areas in organic production is to be achieved in the future. The wine sector in Slovenia is facing major problems with the sale and marketing of wine and, above all, annual wine prices. Without the aid of the CAP, winegrowers would not be financially able to carry out the restructuring of vineyards by planting new vine varieties and arranging vineyard areas to improve productivity at work in vineyards, adaptations of vineyards to climate change and sophisticated processing in vineyards in terms of the machinery. While meat consumption is increasing in Slovenia, without the aid of CAP measures, agricultural holdings in Slovenia alone would not be financially able to meet market demand and adapt agricultural production to market needs. With the loss of sales channels and connections in the agri-food industry, there is a great risk of creating new marketing channels from abroad or even third countries outside the EU to meet the needs for meat in Slovenia, thereby reducing food safety in Slovenia and consequently in the EU.

\section{CONCLUSION}

In this paper, the indicators for analysing the First Pillar of the CAP were presented during the period 2014 to 2020. The challenge for future research work can be recognized to analyse the most important measures for Slovenia from second pillar. The limitation of presented research work is recognized that the results cannot be generalized to other countries, but reflect the situation in Slovenian agricultural sector.

\section{REFERENCES}

1. Council for Agricultural Reseach and EconomicsCRA-INEA. (2015). Implementation of the first pillar of the CAP 2014-2020 in the EU member states. Bruselj: Polica Department B: Structural and cohesion policies, agriculture and rural developmnet. Retrieved from: http://www.europarl.europa.eu/studies [5.3.2021]

2. E-democracy. (2014). Resolution on the Strategic Guidelines for the Development of Slovenian Agriculture and Food Industry until 2020. Retrieved from: https:// e-uprava.gov.si/drzava-in-druzba/e-demokracija/ predlogi-predpisov/predlog-predpisa.html?id=5035 [13.3.2021]

3. Erjavec, E., Šumrada, T., Juvančič, L., Rac, I., Cunder, T., Bedrač, M., \& Lovec, M. (2018). Evaluation of the Slovenian agricultural policy in 2015-2020 period. Ljubljana: Agricultural Institute of Slovenia. Retrieved from: https://www.fgg.uni-lj.si/knjizna-novost/ vrednotenje-slovenske-kmetijske-politike-v-obdobju2015-2020/ [5.3.2021]

4. European Commission. (2015). The Monitoring and Evaluation Framework for the Common Agricultural Policy 2014-2020. Luxembourg: Publications Office 
of the EU. Retrieved from: https://op.europa.eu/ en/publication-detail/-/publication/a7aacc47-f819497c-8159-17b925e141bb/language-sl/format-PDF [5.3.2021]

5. European Commission. (2018) Report from the commission to the European parliament and the council on the implementation of the Common Monitoring and Evaluation Framework and first results on the performance of the Common Agricultural Policy. COM (2018) 790 final (5.12.2018). Retrieved from: https://eur-lex.europa.eu/ legal-content/SL/ALL/?uri=CELEX\%3A52018DC0790 [10.3.2021]

6. European Commission. (2021a). CAP Indicators. Retrieved from: https://agridata.ec.europa.eu/ extensions/DataPortal/cmef_indicators.html [10.3.2021]

7. European Commission. (2021b). Rules and measures to regulate and support the marketing of agricultural products. Retrieved from:https://ec.europa.eu/info/foodfarming-fisheries/key-policies/common-agriculturalpolicy/market-measures/market-measures-explained_sl [10.3.2021]

8. European Commission. (2021c). The common agricultural policy is about our food, the environment and the countryside. Retrieved from: https:/ec.europa. eu/info/food-farming-fisheries/key-policies/commonagricultural-policy_sl [10.3.2021]

9. European Union. (2014). Laying down rules for the application of the common monitoring and evaluation framework of the common agricultural policy. Official Journal of the European Union 837/2014. Retrieved from: https://eur-lex.europa.eu/legal-content/SL/TX $\mathrm{T} /$ ? uri=uriserv\%3 AOJ.L_.2014.230.01.0001.01.SLV [5.3.2021]

10. Ministry of Agriculture, Forestry and Food. (2011). Resolution on the Strategic Guidelines for the Development of Slovenian Agriculture and Food Industry until 2020"Zagotovimo.si hrano za jutri" (SURS). Official Journal of the RS, no. 92/07 - official consolidated text and 105/10. Retrieved from: http://www.pisrs.si/Pis.web/ pregledPredpisa?id=RESO80 [10.3.2021]

11. Ministry of Agriculture and the Environment. (2014). Resolution on the Strategic Guidelines for the Development of Slovenian Agriculture and Food Industry until 2020. Ljubljana: MKGP. Retrieved from: http://www.pisrs.si/ Pis.web/pregledPredpisa?id=STRA67 [5.3.2021]

12. Ministry of Agriculture, Forestry and Food. (2018). Situation in the field of viticulture and winemaking in Slovenia. Ljubljana: MKGP. Retrieved from: https://www. gov.si/teme/vinogradnistvo-in-vinarstvo/ [10.3.2021]

13. Ministry of Agriculture, Forestry and Food. (2019). Guidelines for the implementation of agricultural policy measures 2020. Ljubljana: MKGP.

14. Statistical Office of the Republic of Slovenia. (2021). The SI-STAT database, Calendar balances of production and consumption of agricultural products for 2019 are prepared on the basis of final data. Ljubljana: SURS and KIS. Retrieved from: www.stst.si [30.3.2021]

15. Turk, J. (2021). Agricultural policy. Maribor: University of Maribor, Faculty of Agriculture and Life Sciences. 


\section{Analiza I. stebra skupne kmetijske politike (SKP) s pomočjo vrednotenja izbranih kazalcev in ugotavljanje njegovega vpliva na slovensko kmetijstvo v obdobju 2014-2020}

\section{IZVLEČEK}

Skupna kmetijska politika (SKP) obstaja na nivoju Evropske unije že od leta 1962. Skozi obdobja je doživela različne preobrazbe, reforme in prilagoditve. Z merjenem uspešnosti izvajanja SKP je Evropska unija uvedla model vrednotenja posameznih ukrepov SKP skozi uvedbo sistema različnih kazalnikov, ki jih skozi različne metode zbiranja podatkov in informacij objavlja večinoma na letni ravni ter javnosti poroča o njihovih doseženih vrednostih. Na osnovi teh podatkov lahko ocenjujemo, kako uspešno SKP vpliva na posamezne kmetijske panoge znotraj posamezne države ali regije. Slovenija si je z Resolucijo o strateških usmeritvah razvoja slovenskega kmetijstva in živilstva do leta 2020 postavila svoje strateške cilje in svoj prilagojen sistem kazalnikov za vrednotenje. Z analizo I. stebra SKP želimo oceniti vpliv SKP na slovensko kmetijstvo v obdobju 2014-2020 na osnovi izbranih kazalnikov in sicer za ekološko kmetijstvo, vinski sektor in oceno samooskrbe za izbran kmetijski proizvod - meso. Izvedena analiza doseženih rezultatov je lahko podlaga za oceno uspešnosti ukrepov SKP in vhodna informacija odločevalcem pri nadaljnjem razvoju ustreznih ukrepov SKP v prihodnosti. Rezultati lahko služijo kot nadaljnji izhodni podatki za mnoge raziskave (ena izmed takšnih je ocena uspešnosti vloženih finančnih sredstev SKP v posamezne ciljne ukrepe SKP in njihovih dosežkih).

Ključne besede: Skupna kmetijska politika (SKP), Prvi steber, vrednotenje kazalnikov, ekološko kmetijstvo, vino, samooskrba z mesom 